\title{
Sifat Fisik dan Kimia Daging Kelinci Rex dan Lokal (Oryctolagus cuniculus)
}

\section{Physical and Chemical Properties of Rex and Local Rabbit's (Oryctolagus cuniculus) Meat}

\author{
B. Brahmantiyo ${ }^{1}$, Setiawan, M. A., ${ }^{2}$ dan M. Yamin ${ }^{2}$ \\ ${ }^{1}$ Balai Penelitian Ternak, Jl Veteran III, Ciawi PO BOX 221, Bogor 16002 \\ ${ }^{2}$ Fakultas Peternakan IPB, Jl. Agathis Kampus IPB Darmaga, Bogor 16680 \\ e-mail: brahmantiyo@gmail.com
}

(Diterima: 11 November 2013; Disetujui: 19 Februari 2014)

\begin{abstract}
ABSTRAK
Kelinci berpotensi sebagai alternatif sumber protein hewani. Daging kelinci mengandung protein tinggi dan kandungan lemak yang rendah dibandingkan dengan daging ternak lain. Saat ini, informasi terkait performa karkas kelinci Rex dan lokal masih sangat kurang. Penelitian ini bertujuan untuk mangetahui performa karkas, perlakuan fisik dan kimia pada daging kelinci Rex dan lokal. Analisis statistik yang digunakan pada penelitian ini adalah Rancangan Faktorial 2x2 dengan 3 kali ulangan. Faktor pertama adalah jenis kelinci dan faktor kedua adalah jenis kelamin. 6 ekor kelinci Rex dan kelinci lokal yang digunakan pada penelitian ini adalah 3 jantan dan 3 betina. Hasil penelitian menunjukkan bahwa kelembaban daging kelinci Rex lebih tinggi dibandingkan dengan kelinci lokal $(\mathrm{P}<0,05)$. Kelinci betina memiliki nilai $\mathrm{pH}$, keempukan dan daya ikat air yang lebih baik dibanding kelinci jantan $(\mathrm{P}<0,05)$. Perbedaan antar perlakuan dipengaruhi oleh manajemen pemeliharaan, perlakuan sebelum antemortem dan postmortem, dan juga aktivitas kelinci.
\end{abstract}

Kata kunci: kelinci Rex, kualitas fisik dan kimia

\section{ABSTRACT}

Rabbits had a potention as an alternative source of animal protein. Rabbit's meat contain higher protein with less fat in comparing with other livestock meat. Nowadays, the information about the performance of Rex and local rabbit's carcass is still lack. The aims of this research determined the performance of carcass, physical and chemical traits of Rex and local rabbit meat. This experiment was designed by using factorial design with two factors. The first factor was rabbit breed and the second one was sex of rabbit. Six Rexs and local rabbits were used in this research ( 3 males and 3 females). Physical and chemical traits were observed. The result showed that meat moisture of Rex rabbit were higher than local breed $(P<0.05)$. The female rabbit showed better in $\mathrm{pH}$ value, tenderness, water holding capacity than male $(P<0.05)$. The differences between treatment were influenced by maintenance management, treatment before antemortem and postmortem, also rabbit activities.

Keywords: Rex rabbit, physical and chemical quality

\section{PENDAHULUAN}

Kelinci mulai dikenal sebagai ternak alternatif penghasil daging karena keunggulan reproduksi yang tinggi, pertumbuhan yang baik dan mampu beradaptasi dengan pakan lokal. Selain itu, kualitas daging yang dicerminkan dengan kandungan nutrisi seperti protein yang tinggi dengan kandungan lemak dan kolesterol rendah menjadikan daging kelinci sebagai daging sehat. Hal ini mendorong perkembangan ternak kelinci menjadi ternak penghasil daging di beberapa daerah sentra kelinci seperti Berastagi Medan, Lembang Bandung dan Batu Malang serta daerah lainnya.

Kelinci Rex merupakan kelinci yang dapat menghasilkan kulit rambut (fur) ber- 
kualitas dengan perdagingan yang baik sehingga dikenal sebagai kelinci dual purposes. Kelinci Rex juga banyak dikembangkan sebagai kelinci hias yang banyak diperlombakan karena kehalusan rambutnya menyerupai beludru. Beberapa asosiasi peternak kelinci Jakarta Rex Rabbit Club, Indonesian Rabbit Club dikenal sebagai asosiasi yang memperlombakan kelinci Rex sebagai kelinci hias dengan standar penilaian mengacu pada American Rabbit Breeder Association (1996).

Kelinci lokal adalah kelinci yang banyak dipelihara oleh peternak dengan tujuan menghasilkan anakan kelinci dan dapat pula sebagai penghasil daging. Anakan kelinci lokal cukup populer diperjualbelikan di pasar-pasar tradisional ataupun daerah-daerah wisata dataran tinggi. Kelinci dewasa yang sudah tidak bereproduksi ataupun kelinci yang sakit akan dipotong dan dijadikan kelinci pedaging. Kelinci ini memiliki daya adaptasi yang tinggi dengan pakan lokal seperti limbah sayuran, gulma di ladang sayur dan hasil sortir tanaman umbi-umbian.

Kelinci merupakan salah satu hewan yang menjadi perhatian dunia untuk dijadikan sebagai alternatif sumber protein. Kelinci dikenal sebagai ternak yang mempunyai kemampuan reproduksi yang tinggi dengan interval kelahiran yang pendek, tidak membutuhkan lahan luas dalam pemeliharaannya dan keragaman jenis yang tinggi. Selain itu, kelinci juga memiliki kadar protein daging yang tinggi dan kadar lemak daging yang rendah jika dibandingkan dengan daging yang berasal dari ternak lain (Farrel dan Raharjo, 1984; Lebas et al., 1986).

Karakter sifat fisik dan kimia daging kelinci, baik Rex maupun lokal masih sangat terbatas. Penelitian menggali informasi produktivitas kelinci lokal dan Rex dilakukan sebagai dasar pengembangan potensi kelinci sebagai penghasil daging berkualitas.

\section{METODE}

Penelitian ini dilaksanakan di Balai Penelitian Ternak (Balitnak), Bagian Kelinci, Ciawi, Bogor, Jawa Barat dan peternakan kelinci milik penduduk di desa Banjarwaru, Ciawi, Bogor. Ternak yang digunakan pada penelitian ini adalah kelinci Rex dan kelinci lokal, masing-masing sebanyak 12 ekor (6 ekor jantan dan 6 ekor betina), jadi total ternak yang digunakan adalah 24 ekor. Kelinci Rex diberikan ransum berbentuk pelet dengan kandungan nutrisi protein kasar $18 \%$ dan energi $2700 \mathrm{kkal} / \mathrm{kg}$, jumlah pemberian 100150 g/ekor/hari, air minum disediakan ad-libitum. Kelinci dikandangkan individu dengan kandang terbuat dari kawat. Kelinci lokal diberi pakan hijauan dengan tambahan campuran dedak dan ampas tahu, air diberikan ad-libitum. Kandang yang digunakan adalah kandang individu yang terbuat dari bambu dengan sisi bagian depan terbuat dari kawat.

Kelinci dipotong setelah dipuasakan selama 12 jam, pemotongan dilakukan dengan memotong bagian leher, sehingga semua pembuluh darah (arteri dan vena), saluran pernafasan dan saluran pencernaan terpotong. Pengulitan, pemotongan kepala (sendi occipito atlantis), kaki depan, kaki belakang dan ekor, kemudian ditimbang. Setelah selesai dikuliti, semua isi rongga perut dan dada dikeluarkan dan ditimbang tiap bagian-bagiannya. Karkas kemudian ditimbang dan ditempatkan di ruang pendingin (refrigerator) selama 24 jam. Selanjutnya, karkas dipotong menjadi 4 potongan komersial, yaitu foreleg, rack, loin dan hindleg dan ditimbang. Potongan komersial Hindleg dibawa ke laboratorium untuk digunakan sebagai bahan untuk analisis proksimat dan uji fisik daging.

\section{HASIL DAN PEMBAHASAN}

\section{Sifat Fisik}

Sifat fisik yang diamati pada penelitian ini adalah nilai $\mathrm{pH}$, keempukan, susut masak dan daya mengikat air (DMA). Hasil uji fisik yang diperoleh dapat dilihat pada Tabel 1.

Lawrie (2003) menyatakan penurunan $\mathrm{pH}$ daging disebabkan akumulasi dari asam laktat setelah pemotongan. Hasil uji sifat fisik menunjukkan bahwa jenis kelamin (sex) berpengaruh terhadap nilai $\mathrm{pH}(\mathrm{P}<0,05)$. Uji lanjut yang dilakukan menunjukkan bahwa $\mathrm{pH}$ kelinci lokal betina $(6,13 \pm 0,19)$ berbeda 
Tabel 1. Karakteristik sifat fisik daging kelinci

\begin{tabular}{lcccc}
\hline \multirow{2}{*}{ Karakteristik } & \multicolumn{2}{c}{ Rex } & \multicolumn{2}{c}{ Lokal } \\
\cline { 2 - 5 } & \multicolumn{1}{c}{ Jantan } & Betina & Jantan & Betina \\
\hline $\mathrm{pH}$ & $5,86 \pm 0,16^{\mathrm{ab}}$ & $5,92 \pm 0,24^{\mathrm{ab}}$ & $5,67 \pm 0,07^{\mathrm{a}}$ & $6,13 \pm 0,19^{\mathrm{b}}$ \\
Keempukan $\left(\mathrm{kg} / \mathrm{cm}^{2}\right)$ & $4,54 \pm 0,13^{\mathrm{a}}$ & $4,44 \pm 0,42^{\mathrm{a}}$ & $4,12 \pm 0,30^{\mathrm{a}}$ & $1,98 \pm 1,46^{\mathrm{b}}$ \\
Susut masak $(\%)$ & $36,01 \pm 4,19^{\mathrm{a}}$ & $35,63 \pm 3,84^{\mathrm{a}}$ & $40,77 \pm 3,28^{\mathrm{a}}$ & $40,48 \pm 3,50^{\mathrm{a}}$ \\
DMA $\left(\mathrm{mgH}_{2} \mathrm{O}\right)$ & $104,71 \pm 13,02^{\mathrm{a}}$ & $122,18 \pm 9,06^{\mathrm{ab}}$ & $108,57 \pm 12,87^{\mathrm{ab}}$ & $133,29 \pm 18,52^{\mathrm{b}}$ \\
\hline
\end{tabular}

Keterangan: DMA = Daya Mengikat Air

Huruf superskript menandakan berbeda nyata, huruf kecil $\mathrm{P}<0,05$

dengan $\mathrm{pH}$ kelinci lokal jantan $(5,67 \pm 0,07)$. Variasi nilai $\mathrm{pH}$ terhadap jenis kelamin pada kelinci lokal jantan $(5,67 \pm 0,07)$ dan betina $(6,13 \pm 0,19)$ disebabkan oleh tingkah laku kelinci tersebut. Umumnya jantan mempunyai tingkah laku yang lebih agresif dibandingkan dengan betina, sehingga otot pada jantan lebih aktif. Kandungan asam laktat yang dihasilkan oleh kelinci jantan akan lebih banyak dibandingkan dengan kelinci betina, sehingga $\mathrm{pH}$ akhir dari jantan akan lebih asam. Buckle et al. (2007) menyatakan bahwa perubahan $\mathrm{pH}$ sesudah ternak mati pada dasarnya ditentukan oleh kandungan asam laktat yang tertimbun dalam otot, selanjutnya oleh kandungan glikogen dan penanganan sebelum penyembelihan.

Nilai pH pada penelitian ini, baik kelinci lokal maupun kelinci Rex, jantan atau betina, mempunyai nilai $\mathrm{pH}$ yang tidak berbeda dengan $\mathrm{pH}$ ultimat daging secara umum, yaitu 5,4-5,85 (Soeparno, 1992). pH ultimat daging kelinci hampir sama dengan kebanyakan daging dari ternak lain (Blasco et al., 1992). Stres sebelum pemotongan, pemberian suntikan hormon atau obat-obatan tertentu, spesies, individu ternak, macam otot stimulasi listrik dan aktivitas enzim yang mempengaruhi glikolisis adalah faktor-faktor yang dapat menghasilkan variasi pH daging (Soeparno, 1992).

Beberapa aspek yang memberikan gambaran keempukan daging meliputi tekstur dan melibatkan tiga aspek. Pertama, mudah tidaknya gigi berpenetrasi awal ke dalam daging. Kedua, mudah tidaknya daging tersebut dipecah menjadi bagian-bagian yang lebih kecil. Ketiga, jumlah residu tertinggal setelah diku- nyah (Lawrie, 2003). Daging sangat empuk memiliki daya Warner Blatzler $(W B)<4,15$ $\mathrm{kg} / \mathrm{cm}^{2}$, daging empuk $4,15-<5,86 \mathrm{~kg} / \mathrm{cm}^{2}$, daging agak empuk $5,86-<7,56 \mathrm{~kg} / \mathrm{cm}^{2}$, daging agak alot $7,56-9,27 \mathrm{~kg} / \mathrm{cm}^{2}$, daging alot $9,27-<10,27 \mathrm{~kg} / \mathrm{cm}^{2}$, daging sangat alot $\geq 10,97 \mathrm{~kg} / \mathrm{cm}^{2}$ (Arief et al., 2006).

Hasil penelitian ini menunjukkan bahwa rumpun (breed) maupun jenis kelamin (sex) sama-sama berpengaruh sangat nyata $(\mathrm{P}<0,01)$ terhadap nilai keempukan daging kelinci. Hal ini sesuai dengan Soeparno (1992) yang menyatakan bahwa faktor antemortem yang mempengaruhi keempukan daging ialah rumpun, spesies dan fisiologi, faktor umur, manajemen, jenis kelamin dan stres.

Rataan nilai keempukan pada kelinci lokal betina $\left(1,98 \pm 1,46 \mathrm{~kg} / \mathrm{cm}^{2}\right)$ lebih baik dibandingkan dengan kelinci lainnya $(4,12-$ $\left.4,54 \mathrm{~kg} / \mathrm{cm}^{2}\right)$. Perbedaan keempukan pada jenis rumpun ini disebabkan tipe jenis kelinci. Kelinci Rex merupakan tipe kelinci medium sedangkan kelinci lokal adalah tipe kelinci kecil. Tipe kelinci medium memiliki serabut otot yang lebih besar dibandingkan kelinci tipe kecil. Hal ini menyebabkan perbedaan keempukan pada kedua jenis rumpun ini. Soeparno (1992) menyatakan bahwa perbedaan rumpun dapat menimbulkan perbedaan keempukkan. Hal ini terkait dengan tipe rumpun. Ternak tipe kecil relatif memiliki tekstur yang lebih halus dibandingkan ternak tipe besar.

Jenis kelamin juga mempengaruhi rataan nilai keempukan pada penelitian ini. Rataan nilai keempukan pada jantan $(4,33 \pm 0,31)$ lebih tinggi daripada kelinci betina $(3,21 \pm 0,31)$. Hal 
ini disebabkan perilaku kelinci jantan yang lebih banyak bergerak dibandingkan dengan kelinci betina sehingga kontraksi otot pada kelinci jantan lebih banyak dibandingkan kelinci betina. Brahmantiyo (2000), menyatakan bahwa aktivitas otot mempengaruhi keempukan dari daging.

Hasil rataan nilai keempukan pada penelitian ini $\left(1,98-4,54 \mathrm{~kg} / \mathrm{cm}^{2}\right)$ termasuk kategori empuk. Hal ini karena pemeliharaan kelinci, baik lokal maupun rex, menggunakan kandang individu. Kelinci yang dipelihara di dalam kandang individu relatif sedikit melakukan aktivitas gerak dibandingkan kelinci yang dipelihara pada kandang koloni. Aktivitas gerak yang sedikit pada kelinci tersebut akan mengurangi kontraksi otot, terutama pada otot - otot rangka tulang gerak, sehingga keempukan daging akan meningkat/bertambah. Aberle et al. (1981) menyatakan bahwa domba yang dipelihara dalam kandang individu relatif lebih sedikit melakukan aktivitas gerak dibandingkan domba yang dipelihara pada kandang koloni, lebih-lebih pada domba yang digembalakan setiap hari. Aktivitas gerak pada domba dimungkinkan mampu meningkatkan kontraksi otot, terutama pada otototot rangka tulang gerak, sehingga keempukan daging berkurang.

Susut masak merupakan perbedaan antara bobot daging sebelum dan sesudah dimasak dan dinyatakan dalam persentase. Daging dengan susut masak yang lebih rendah mempunyai kualitas yang relatif lebih baik daripada daging dengan susut masak yang lebih besar. Kualitas daging ini berkaitan dengan banyaknya nutrisi yang hilang selama pemasakan. Secara umum daging dengan susut masak yang rendah memiliki nutrisi yang baik, karena sedikit mengalami pengurangan nutrisi saat pemasakan.

Hasil penelitian ini menunjukkan bahwa rumpun (breed) dan jenis kelamin (sex) maupun interaksi antar keduanya, tidak berpengaruh nyata $(\mathrm{P}>0,05)$ terhadap susut masak. Nilai susut masak pada kelinci Rex $(35,82 \pm 1,52)$ lebih kecil daripada kelinci lokal $(40,62 \pm 1,52)$, tetapi perbedaan tersebut tidak sampai berbeda nyata saat uji statistik. Hal ini karena jumlah nutrien yang keluar saat pemasakan adalah sama untuk kelinci lokal maupun kelinci Rex.

Rumpun (breed) dapat juga berpengaruh terhadap susut masak. Rumpun yang mempunyai kandungan lemak daging yang tinggi akan mempunyai susut masak yang tinggi pula (Soeparno, 1992). Lemak tersebut akan ikut keluar saat pemasakan. Kelinci Rex dan kelinci lokal tidak mempunyai kandungan lemak yang jauh berbeda, sehingga nilai susut masaknya tidak berbeda nyata. Soeparno (1992) menyatakan bahwa jenis kelamin (sex) mempunyai pengaruh yang kecil terhadap susut masak.

Daya ikat air oleh protein daging atau water-holding capacity atau water binding capacity (WHC dan WBC) adalah kemampuan daging untuk mengikat airnya atau air yang ditambahkan selama ada pengaruh kekuatan dari luar. Daya mengikat air daging dipengaruhi oleh faktor yang mengakibatkan perbedaan daya mengikat air di antara otot, misalnya spesies, umur dan fungsi otot serta pakan, transportasi, temperatur kelembaban, penyimpanan dan preservasi, jenis kelamin, kesehatan, perlakuan sebelum pemotongan dan lemak intramuskuler (Soeparno, 1992).

Hasil penelitian ini menunjukkan bahwa jenis kelamin (sex) berpengaruh nyata terhadap daya mengikat air pada daging kelinci. Kelinci lokal betina mempunyai rataan nilai DMA $(133,29 \pm 18,52)$ yang lebih tinggi dibandingkan dengan kelinci Rex jantan $(104,71 \pm 13,02)$. Hal ini disebabkan kelinci lokal betina lebih pasif dalam aktivitasnya daripada kelinci Rex jantan, sehingga $\mathrm{pH}$ daging pada lokal betina lebih tinggi dibandingkan dengan kelinci Rex jantan. pH rendah pada daging akan membuat air yang berasosiasi dengan protein otot akan keluar dari daging, sehingga DMA daging menurun. Soeparno (1992) menyatakan periode pembentukan asam laktat yang menyebabkan penurunan $\mathrm{pH}$ otot postmortem, menurunkan DMA daging dan banyak air yang berasosiasi dengan protein otot akan bebas meninggalkan serabut otot. 
Tabel 2. Karakteristik sifat kimia daging kelinci

\begin{tabular}{lcccc}
\hline Karakteristik & \multicolumn{2}{c}{ Rex } & \multicolumn{2}{c}{ Lokal } \\
\cline { 2 - 5 } & Jantan & Betina & Jantan & Betina \\
\hline Kadar air & $72,73 \pm 0,52^{\mathrm{ab}}$ & $70,57 \pm 2,51^{\mathrm{a}}$ & $73,27 \pm 0,76^{\mathrm{b}}$ & $75,03 \pm 0,79^{\mathrm{b}}$ \\
Abu & $1,08 \pm 0,12^{\mathrm{A}}$ & $1,10 \pm 0,03^{\mathrm{A}}$ & $1,06 \pm 0,05^{\mathrm{A}}$ & $1,19 \pm 0,03^{\mathrm{A}}$ \\
Lemak kasar & $2,20 \pm 1,32^{\mathrm{A}}$ & $5,01 \pm 1,42^{\mathrm{B}}$ & $1,34 \pm 0,64^{\mathrm{A}}$ & $0,89 \pm 0,28^{\mathrm{A}}$ \\
Protein kasar & $18,78 \pm 0,78^{\mathrm{A}}$ & $18,50 \pm 1,20^{\mathrm{A}}$ & $18,36 \pm 0,58^{\mathrm{A}}$ & $18,77 \pm 0,93^{\mathrm{A}}$ \\
GE (kal/g) & $1572,67 \pm 165,17^{\mathrm{AB}}$ & $1411,67 \pm 279,43^{\mathrm{A}}$ & $1860,67 \pm 120,35^{\mathrm{B}}$ & $1310,00 \pm 86,43^{\mathrm{A}}$ \\
\hline
\end{tabular}

Keterangan: GE = Gross Energi

Huruf superskript menandakan berbeda nyata, huruf kecil $\mathrm{P}<0,05$ dan huruf besar $\mathrm{P}<0,01$

\section{Sifat Kimia}

Uji kimia daging merupakan uji yang dilakukan untuk mengetahui kandungan kimia (nutrisi) yang terkandung pada daging dan umumnya ditentukan dengan menggunakan analisis proksimat. Uji kimia daging yang dilakukan pada penelitian ini meliputi kadar air (KA), abu, lemak kasar, protein kasar dan energi kotor (GE). Hasil uji kimia pada penelitian ini dapat dilihat pada Tabel 2.

Ketersediaan air sangat mempengaruhi ketahanan daging sebagai bahan pangan khususnya dalam konteks kerusakan mikrobiologis. Air yang terukur dengan metode pemanasan langsung merupakan air yang menguap karena titik didihnya terlampaui dan air yang hilang selama pemanasan dengan oven $\left( \pm 105^{\circ} \mathrm{C}\right)$ meliputi air permukaan maupun air pada bagian dalam daging (Lawrie, 2003).

Hasil penelitian ini menunjukkan bahwa jenis rumpun dan interaksi antara jenis rumpun dan jenis kelamin berpengaruh nyata $(\mathrm{P}<0,05)$ terhadap kadar air daging kelinci. Rataan kadar air kelinci betina Rex (70,57 \pm 2,51) lebih kecil daripada rataan kadar air kelinci jantan dan betina lokal (73-75\%). Total rataan nilai kadar air pada semua kelinci di penelitian ini (70-75\%) sesuai dengan Judge et al., (1989) yang menyatakan bahwa kisaran air daging pada umumnya adalah 65$80 \%$. Variasi kadar air pada kelinci Rex dan kelinci lokal disebabkan kelinci Rex mempunyai tingkat dehidrasi yang lebih tinggi dibandingkan kelinci lokal, sehingga kadar air daging pada kelinci Rex sedikit lebih kecil di- bandingkan dengan kelinci lokal. Lawrie (2003) menyatakan bahwa kadar air daging segar lebih dipengaruhi tingkat dehidrasi ternak sebelum pemotongan.

Kadar abu dalam suatu bahan yang diuji dapat menggambarkan jumlah mineral yang terkandung dalam bahan tersebut. Nilai kadar abu yang semakin tinggi maka kandungan mineral akan semakin tinggi pula. Mineral tersebut dapat merupakan garam organik maupun anorganik. Kadar abu daging kelinci pada penelitian ini tidak dipengaruhi oleh jenis rumpun, jenis kelamin dan interaksi antar keduanya. Rataan nilai kadar abu untuk semua kelinci pada penelitian ini $(1,06-1,19 \%)$. Hasil penelitian ini menunjukkan bahwa daging kelinci Rex dan kelinci lokal mempunyai kandungan abu (mineral) yang tidak berbeda. Hal ini disebabkan pakan yang diberikan pada kedua kelinci ini mempunyai kandungan mineral yang sama, sehingga kadar abu yang diperoleh tidak jauh berbeda.

Kadar protein kasar yang terukur secara proksimat sebenarnya bukan hanya fraksi protein tetapi juga semua senyawa yang mengandung nitrogen. Kadar protein merupakan salah satu indikator yang sangat penting dalam suatu bahan pangan. Bahan pangan yang berkualitas mempunyai kadar protein yang tinggi.

Hasil penelitian ini menunjukkan bahwa rataan kadar protein daging kelinci mempunyai nilai yang tidak berbeda, yaitu $18 \%$. Hal ini berarti jenis rumpun dan jenis kelamin serta interaksi kedua faktor ini tidak berpengaruh terhadap kadar protein daging. Ngadiono (1992) menyatakan bahwa kadar 
protein dan abu dalam daging relatif konstan. Rataan nilai kadar protein daging pada penelitian ini (18\%) lebih kecil dari kadar protein yang dilaporkan oleh Lebas et al. (1986) yaitu sebesar 20,8\%. Hal ini disebabkan pakan yang diberikan untuk kelinci rex maupun lokal mempunyai kandungan protein yang lebih kecil dibandingkan dengan pakan yang digunakan Lebas et al. (1986) sehingga protein yang diserap tubuh lebih sedikit.

Kadar lemak bervariasi dan dipengaruhi oleh rumpun, umur, spesies, lokasi otot dan pakan (Judge et al., 1989). Hasil penelitian ini menunjukkan bahwa jenis rumpun berpengaruh sangat nyata $(\mathrm{P}<0,01)$ dan interaksi antara jenis rumpun dan jenis kelamin berpengaruh nyata $(\mathrm{P}<0,05)$ terhadap kadar lemak karkas daging kelinci. Kelinci Rex memiliki rataan kadar lemak yang lebih tinggi (2,20-5,01\%) dibandingkan dengan kelinci lokal $(0,89-1,34 \%)$. Hal ini disebabkan kelinci Rex merupakan kelinci jenis hias yang tingkah lakunya agak jinak dibandingkan dengan kelinci lokal, sehingga energi dari pakan yang dikonsumsi lebih banyak dideposit menjadi lemak ketimbang untuk bergerak. Selain itu kelinci Rex merupakan kelinci subtropis, sehingga perlemakannya lebih banyak ketimbang dengan kelinci lokal yang hidup di lingkungan tropis.

Hubungan antara kadar air dengan kadar lemak pada penelitian ini sesuai dengan Soeparno (1992) yang menyatakan bahwa kadar air otot daging mempunyai korelasi negatif yang signifikan dengan kadar air lemak daging. Hasil penelitian menunjukkan bahwa kelinci Rex dengan kadar air yang lebih kecil dibandingkan kelinci lokal, mempunyai kandungan lemak kasar yang lebih besar daripada kelinci lokal.

Pengujian gross energi ini menggunakan sampel daging pada pada bagian hindleg. Hasil penelitian menunjukkan bahwa jenis kelamin berpengaruh sangat nyata $(\mathrm{P}<0,01)$ terhadap kandungan energi kotor pada daging kelinci. Rataan gross energi kelinci jantan (1716 kal/g) lebih besar dibandingkan kelinci betina $(1360 \mathrm{kal} / \mathrm{g})$. Hal ini disebabkan oleh tingkah laku jantan yang mempunyai perilaku makan yang lebih besar dibandingkan dengan betina, sehingga pakan yang dikonsumsi lebih banyak pada jantan yang selanjutnya akan mempengaruhi kandungan energi dagingnya. Kadar gross energi pada penelitian ini (1310 $1860 \mathrm{kal} / \mathrm{g}$ ) masih di bawah kadar gross energi yang dilaporkan oleh Lebas et al. (1986) 7,1 $\mathrm{MJ} / \mathrm{kg}$. Hasil konversi gross energi pada penelitian ini adalah $6,1 \mathrm{MJ} / \mathrm{kg}$. Hal ini disebabkan kandungan energi pakan yang digunakan berbeda. Ulil (2000) menyatakan bahwa perbedaan energi daging dapat disebabkan oleh perbedaan energi ransum.

\section{KESIMPULAN}

Karakteristik sifat fisik dan kimia daging kelinci Rex dengan kelinci lokal mempunyai perbedaaan nilai $\mathrm{pH}$, keempukan, daya mengikat air, kadar air, lemak dan gross energi. Sifat fisik dan kimia daging kelinci Rex lebih baik daripada kelinci lokal. Kelinci betina menghasilkan nilai peubah yang lebih baik dibandingkan dengan jantan. Variasi perbedaan tersebut dipengaruhi oleh manajemen pemeliharaan (pakan), perlakuan sebelum pemotongan dan aktivitas ternak (perilaku).

\section{DAFTAR PUSTAKA}

Aberle, E. D., E. S. Reeves, M. D. Judge, R. E. Hunsley, and T. W. Perry. 1981. Palatability and muscle characteristic of cattle with controlled weight gain: time on a high energy diet. J. Anim. Sci. 52: 757-763.

American Rabbit Breeders Association. 1996. Official Guide Book "To Raising Better Rabbit and Cavies". The American Rabbit Breeders Assosiation, Inc. Blomington Illionis 61704.

AOAC. 1999. Official Methods of Analysis of the Association of Official Analytical Chemist. Association of Official Analytical Chemist. Washington, USA.

Arief, I. I., T. Suryati dan R. R. A. Maheswari. 2006. Sifat fisik daging 
sapi dark firm dry (DFD) hasil fermentasi bakteri asal laktat Lactobacillus plantarum. Med Pet Vol. 29(2):76-82.

Blasco, A., J. Ouhayoun and G. Masoero. 1992. Study of rabbit meat and carcass : criteria and terminology. J. Appl. Rabbit Res. 15:775-786.

Brahmantiyo, B. 2000. Sifat fisik dan kimia daging sapi Brahman Cross, Murray Grey dan Angus. Med Vet. 7(2):9-11.

Buckle, K. A., R. A. Edwards, G. H. Fleet dan M. Wootton. 2007. Ilmu Pangan. Terjemahan. Purnomo dan Adiono. Universitas Indonesia Press, Jakarta.

Farrel, D. J. dan Y. C. Rahardjo. 1984. Potensi ternak kelinci sebagai penghasil daging. Pusat Penelitian dan Pengembangan Peternakan, Bogor.

Judge, M. D., E. D. Aberle, J. C. Forrest, H.B. Hedrick and R.S. Merkel. 1989. Principles of Meat Science. $2^{\text {nd }}$. Ed. Kendall / Hunt Publishing Co. Dubuque,
Iowa.

Lawrie, R. A. 2003. Meat Science. $5^{\text {th }}$ Ed. Perganon Press, Oxford.

Lebas, F., P. Coudet, R. Rouvier and H. de Rochambeau. 1986. The Rabbit, Husbandry, Health and Production. FAO. Animal Production and Health Series No. 21. Rome, Italy.

Ngadiyono, N. 1995. Pertumbuhan serta sifatsifat karkas dan daging sapi Sumba Ongole, Brahman Cross dan Australian Commercial Crosses yang dipelihara secara intensif pada berbagai bobot potong. Disertasi. Fakultas Pascasarjana IPB, Bogor.

Soeparno. 1992. Ilmu dan Teknologi Daging. Gadjah Mada University Press, Yogyakarta.

Ulil, A. 2000. Kajian prokdutivitas sifat fisikkimia daging sapi Brahman Cross pada ransum yang berbeda. Disertasi. Program Pasca Sarjana Institut Pertanian Bogor, Bogor. 